\title{
Considerações Gerais sobre o uso da Televisão e do Vídeo na Escola a partir da Experiência de Professores em Sala de Aula no Nível Secundário
}

\author{
General Considerations about the Use of Television and Video in the School from the \\ Experience of Teachers at High Level Classrooms
}

\author{
Milton Souza Ribeiro, Miltão* \\ Departamento de Física - UEFS \\ Campus Universitário, Km 03, BR 116 \\ Feira de Santana - BA - 44036-900
}

Maria Tereza Moraes Simões, Denise Simões Serra e Tânia Cristina R. Sousa

Colégio Estadual Mário Augusto Teixeira de Freitas

Feira de Santana - BA - 44036-900

\begin{abstract}
Nesse trabalho [1], a partir de nossa experiência de professores em sala de aula em uma escola do nível secundário, pretendemos tecer algumas considerações acerca do uso da televisão e do vídeo na escola. O estudo do uso da televisão e do vídeo no $2^{0}$ grau é tema inserido em vasta bibliografia, contudo os professores desse nível de ensino comparecem, em geral, como objeto de tal estudo e não como autores, pesquisadores dessas investigações. Levando em conta as funções do audiovisual, bem como a linguagem subjacente, estabelecemos uma definição para o audiovisual didático-pedagógico para, em seguida, analisar algumas questões, por nós formuladas, relacionadas ao uso da televisão e do vídeo na sala de aula, tecendo algumas considerações com o objetivo de solucioná-las.
\end{abstract}

Palavras-chaves: Televisão, Vídeo, Escola, Ensino Secundário, Audiovisual.

In this work [1], starting from our experience as teachers in classroom of a high level school, we intend to establish some considerations about the use of television and video in the school. The study of television and video usage in the high school is a theme included on a wide literature, however the teachers of this level teaching assume, in general, as object in such study and not as authors, researches of these investigations. Taking into account the functions of the audiovisual, as well as the language, we establish a definition for didacticpedagogical audiovisual to, in a following moment, analyze some questions formulated by us, related to the usage of television and video in classroom, taking considerations with the objective to solve them.

Key-words: Television, Video, School, High Teaching, Audiovisual.

\section{INTRODUÇÃO}

Partindo da premissa de que a educação [2] é fundamentalmente um processo de comunicação, de interação, de relação entre pessoas, damos continuidade ao nosso projeto de pesquisa Estudo do Uso do Livro Didático, Televisão, Vídeo, Cinema e Teatro na Sala de Aula, através do tema televisão e vídeo

${ }^{*}$ Endereço Eletrônico: miltaaao@ig.com.br
[3], por considerarmos urgente educar para a mídia e, principalmente, formar telespectadores críticos.

Essa tarefa não pode ser individual, daí colocar essa discussão no seio da escola. Esse é um desafio que precisa e pode ser enfrentado. Como estabelecemos em [4],

a Educação, considerada como um fenômeno social [5], não é para a sociedade senão o meio pelo qual ela prepara, no intimo dos seres, as condições essenciais da própria 
existência, ou seja, ela cria no indivíduo um ser novo, um ser social [4].

Educação-Leitura Crítica é um constante ajuste no sistema de valores, um processo onde se entrelaçam a decodificação (percepção de mundo) e a valoração (qualificação da percepção), e se misturam decodificação e avaliação (crítica da percepção).

Desde os primórdios o ser humano está num permanente processo de leitura crítica, proporcionando o desenvolvimento da humanidade, a busca da compreensão do mundo, das suas leis, da existência e do futuro. A consciência crítica busca ir além das aparências, percebe a realidade como mutável, é investigadora, alimentase do diálogo, e examina o velho e o novo sem pré-conceitos.

A Escola pode e precisa estabelecer pontes com os meios de comunicação. Pode utilizálos como motivação para o conteúdo de ensino, como ponto de partida mais dinâmico e interessante diante de um novo assunto a ser estudado.

Os meios de comunicação podem, por seu turno, apresentar o próprio conteúdo de ensino (cursos organizados em vídeo, por exemplo), bem como podem ser, eles próprios, objetos de análise, de conhecimento (estudo crítico da TV, do cinema, do teatro, do rádio, de jornais e das revistas).

Ademais, a Escola pode combinar as produções escritas convencionais com as novas produções audiovisuais, principalmente em vídeos, que capacitam o estudante a se expressar de forma mais viva e completa.

A Escola precisa, no seu projeto educativo, considerar a questão dos meios de comunicação e da comunicação como parte integrante, e não marginal, do processo educativo integral do desejado 'estudante-cidadão', visando construir uma sociedade realmente democrática.

Nesse sentido, deve também se voltar para a questão do uso da informática, buscando igualmente esse mesmo objetivo.

$\mathrm{O}$ conjunto desses aspectos nos instigou a investigar a questão do uso do vídeo e da televisão no dia-a-dia da sala de aula.

Para tanto, vamos considerar alguns pressu- postos que fundamentam a nossa abordagem a esse importante tema do processo educacional. Inicialmente, temos que [4]:

(i) em relação à concepção de educação [610], entendemos que deve ser relacional, com o objetivo de promover o processo de interação e as relações de reciprocidade, e deve ser emancipatória, com o objetivo de propiciar o processo de conscientização;

(ii) em relação ao processo de ensinoaprendizagem [6-10], entendemos que deve estar assentado sobre a pedagogia relacional e de ação cultural, embasadas pelas epistemologias construtivista e dialógica, o que viabilizará o processo de interação e conscientização, bem como as relações de reciprocidade; $\mathrm{e}$

(iii) em relação à atividade docente $[2,8,11-$ 14], entendemos que os professores de qualquer instituição educacional, seja ela creche, escola do Ensino Fundamental e Médio ou universidade, devem praticar, de maneira indissociável, as atividades de ensino, pesquisa e extensão.

Sob a égide desses pressupostos, a nossa expectativa com esse trabalho é tecer considerações gerais sobre o uso da televisão e do vídeo na escola, i.e., do audiovisual, a partir da experiência de professores em sala de aula no nível secundário com o fito de contribuir para o debate acerca da formação do cidadão telespectador consciente, ativo e crítico, bem como para a melhoria do currículo das licenciaturas existentes em nossas universidades.

\section{USO DA LINGUAGEM AUDIOVISUAL NA EDUCAÇÃO: UMA TENTATIVA DE DEFINIÇÃO DO AUDIOVISUAL DIDÁTICO-PEDAGÓGICO}


Nessas considerações acerca da linguagem audiovisual, estabeleceremos mais dois pressupostos básicos. Um a respeito das funções ou objetivos do audiovisual e o outro a respeito da sua linguagem.

Inicialmente, a título de conceituação, temos que:

Linguagem é todo sistema de signos que serve de meio de comunicação entre indivíduos e pode ser percebido pelos diversos órgãos dos sentidos, o que leva a distinguirse uma Linguagem Visual, uma Linguagem Auditiva, uma Linguagem Tátil, etc., ou, ainda, outras mais complexas, constituídas, ao mesmo tempo, de elementos diversos [15].

Vale frisar que as noções de informação e linguagem apresentam uma distinção quando tratamos a informação "no contexto filosófico/científico, como conceito de base para a explicação dos processos cognitivos (humanos e não humanos)" [16].

De forma explícita, temos que:

a linguagem humana, simbólica, é ela própria informativa, ou seja, o dominio dos processos informacionais e o dominio dos processos linguísticos simbólicos não são completamente disjuntos [16].

Assim, existem três níveis de processos informacionais [16]: o nível dos processos informacionais não-linguísticos; o nível dos processos informacionais linguísticos nãosimbólicos; e o nível dos processos informacionais linguísticos simbólicos.

Nesse texto, utilizaremos o ponto de vista da concepção antropomórfica do conceito de informação, restringindo-nos aos processos informacionais linguísticos simbólicos; em particular, àqueles em que a linguagem é eminentemente informativa, por ser a dos humanos: a linguagem natural - aquela em que os signos remetem para os predicados, i.e., para as qualidades ou atributos que caracterizam uma coisa.
Além disso, considerando-a como uma abordagem interacional que se vincula com a ideologia, a linguagem, enquanto um sistema de significação da realidade, "é um distanciamento entre a coisa representada e o signo que a representa [sendo que], nessa distância, no interstício entre a coisa e sua representação sígnica (...) reside o ideológico" [17]. Frisemos que, segundo Saussure, "o signo linguístico é arbitrário" [18], unindo um conceito (significado) a uma imagem (significante), que é sensorial.

Vista dessa forma, de acordo com Helena Brandão:

a linguagem não pode ser encarada como uma entidade abstrata, mas como o lugar em que a ideologia se manifesta concretamente, em que o ideológico, para se objetivar, precisa de uma materialidade [17],

um 'signo predicado', a unidade principal constitutiva da linguagem humana e portadora de sentido, qualidade ou atributo.

Nesse aspecto, como assevera Bakhtin,

todo fenômeno que funciona como signo ideológico tem uma encarnação material, seja como som, como massa física, como cor, como movimento do corpo ou como outra coisa qualquer. Nesse sentido, a realidade do signo é totalmente objetiva e, portanto, passivel de um estudo metodologicamente unitário e objetivo. Um signo é um fenômeno do mundo exterior. O próprio signo e todos os seus efeitos (todas as ações, reações e novos signos que ele gera no meio social circundante) aparecem na experiência exterior (...) [e, assim,] cada signo ideológico é não apenas um reflexo, uma sombra da realidade, mas também um fragmento material dessa realidade. (...). [Conclui-se, 
então, que, ] realizando-se no processo da relação social, todo signo ideológico, e, portanto também o signo linguístico, vê-se marcado pelo horizonte social de uma época e de um grupo social determinados [19].

Dessa forma, como premissa para o entendimento do que é linguagem, acompanhamos Helena Brandão quando essa autora estabelece que:

a linguagem (...) como elemento de mediação necessária entre o homem e sua realidade e como forma de engajá-lo na própria realidade, (...) é lugar de conflito, de confronto ideológico, não podendo ser estudada fora da sociedade uma vez que os processos que a constituem são históricosociais; [ou seja], seu estudo não pode estar desvinculado de suas condições de produção [17].

Ainda em termos conceituais, assumimos como linguagem audiovisual a "qualidade de qualquer comunicação destinada simultaneamente aos sentidos da audição e da visão" [20].

Consequentemente, a linguagem audiovisual é considerada como a conjunção das linguagens auditiva e visual, não sendo desconhecido que [20] uma das funções essenciais dessa linguagem é despertar a curiosidade e manter o interesse do receptor.

Filosoficamente falando, o problema da linguagem é estabelecido como:

o problema das relações entre indivíduo e indivíduo. Recebidas as imagens do mundo físico, elaboradas estas imagens no mundo psicológico, o homem tenta comunicar aos outros homens as sensações que delas tirou [21].

Nesse contexto, o mundo físico [21] é a representação da realidade mediante o emprego de instrumentos e de leis os quais significam um primeiro grau do conhecimento do 'mundo tal como ele é', faltando "a tal representação a integração psicológica" [21]; o mundo psicológico "é a representação particular do mundo real obtida no indivíduo mediante a experiência dos sentidos. (...) é o próprio eu, ou seja, a personalidade humana" [21]; e a imagem, por seu turno, são as reproduções, em si, das coisas que o ser humano conhece.

Um princípio filosófico, aqui e agora emerge, o qual assevera que:

admitida e existência do ser, a essência das coisas é, seguramente, por completo distinta de tudo o que possamos pensar em relação às nossas limitadas faculdades cognoscitivas (...), [ou seja, só] poderemos, pelo menos, afirmar a provável existência das coisas independentemente de um ser que as conheça e do ato de conhecer, e, além disso, que o ato de conhecer é uma complicação característica da natureza humana que, enquanto conhece, reproduz em si as imagens das coisas que conhece [21].

Em outras palavras, expressaríamos esse princípio como segue, ainda de acordo com May:

o universo objetivo, exterior a cada um de nós, é, pois, uma entidade que se pode opor ao nosso eu, e que de qualquer modo existe independentemente do nosso modo de conhecê-lo, segundo leis que lhe são próprias: as leis que chamamos naturais (...) [21].

Buscando resolver o problema aludido da linguagem, a linguagem auditiva baseia-se essencialmente no uso da voz, e é também denominada de linguagem falada ou linguagem articulada. É a expressão sonora das mensagens verbais e televisivas. É a articulação dos diversos significantes sonoros (sejam sons, ruídos, silêncios, ou quaisquer materiais 
sensíveis com os quais se expressa a linguagem sonora) em coerência ou não com as idéias expressas no texto.

Por sua vez, a linguagem visual baseia-se essencialmente no uso da visão. É a expressão visual das mensagens impressas e televisivas.

É a articulação dos diversos significantes visuais (sejam cores, formatos, papéis, gênero de impressão, famílias, corpos, medidas, cortes, fios, vinhetas, ilustrações, quadros, etc.; sejam coreografias, cenografias, figurinos, marcação, roteiro, trucagem e outros efeitos especiais, [ou quaisquer materiais sensiveis com os quais se expressa a linguagem visual]), em coerência ou não, com as idéias expressas no texto. Enquanto a escrita ou a fala para chegarem a disparar a ação do receptor precisam ser interpretadas pelo pensamento intelectual, as codificações visuais têm, geralmente, o poder mais instantâneo de comunicação [20].

Observemos, assim, que na linguagem audiovisual, "o estímulo simultâneo aos dois sentidos proporciona maior retenção de informação, melhor assimilação, raciocínio, interesse e imaginação" [20], na busca da solução do aludido problema da linguagem.

Em termos de funções, o audiovisual apresenta as seguintes [20, 22, 23]:

- despertar a curiosidade e manter o interesse do receptor;

- possibilitar o entretenimento da assistência

- levar a informação à assistência;

- propiciar a exposição de conteúdos de forma sistematizada;

- instigar o caráter investigativo da assistência;
- facilitar o desejo de aprofundar o conhecimento de determinado assunto;

- simular situações ou experiências perigosas, bem como que demandariam muito tempo e recursos, além daquelas que não se tem acesso facilmente;

- educar a sociedade.

No que tange à linguagem, o audiovisual apresenta, dentre outras, as seguintes características:

- 1. (...). Usam uma linguagem concreta, plástica, de cenas curtas, com pouca informação de cada vez, com ritmo acelerado e contrastado, multiplicando os pontos de vista, os cenários, os personagens, os sons, as imagens, os ângulos, os efeitos (...);

- 2. (...). A lógica da narrativa não se baseia necessariamente na causalidade, mas na contiguidade em colocar um pedaço de imagem ou estória ao lado da outra (...);

- 3. (...). Os temas são pouco aprofundados, explorando os ângulos emocionais, contraditórios, inesperados (...);

- 4. (...). Passam a informação em pequenas doses (compactos), organizadas em forma de mosaico (rápidas síntese de cada assunto) e com apresentação variada (cada tema dura pouco e é ilustrado) ;

- 5. (...). As mensagens (...) exigem pouco esforço e envolvimento do receptor (...);

- 6. (...). [As linguagens da TV e do vídeo] são dinâmicas, dirigemse antes à afetividade do que a razão [sendo] mais sensorial-visual do que racional e abstrata (...);

- 7. (...). Desenvolve múltiplas atitudes perceptivas (...) [24]. 
Para tanto, o audiovisual utiliza as diferentes funções da linguagem [25] [26-28] como segue:

(i) as produções culturais utilizam, predominantemente, a função emotiva ou expressiva, centrada no destinador ou remetente, objetivando ao emissor exprimir a sua subjetividade, "a suscitar a impressão de uma certa emoção, verdadeira ou simulada" [27];

(ii) as produções específicas utilizam, principalmente, a função referencial, centrada no referente, no contexto, cujo fito é acentuar a característica informativa, ao transmitir ao receptor os dados da realidade de uma forma direta e objetiva;

(iii) as programações de características experimentais têm predominância pela função poética, centrada na mensagem, e evidenciando o lado palpável dos signos, cujo objetivo é subverter e transgredir as normas de uso através dos processos de seleção e combinação sígnica, de maneira afetiva, sugestiva, conotativa e metafórica, projetando "o princípio de equivalência do eixo de seleção sobre o eixo de combinação" [27]: é a linguagem figurada;

(iv) nos programas em geral, em particular nos telejornais e nas propagandas comerciais inseridas nas programações audiovisuais, televisivas principalmente, que objetivam a venda de produtos, predomina a função fática, centrada no contato ou canal, para possibilitar a interação, o contato, entre emissor e receptor (dando a sensação que alguém conversa com o expectador);

(v) nos programas que usam um código [22] para fazer um discurso sobre o próprio código, utilizam a função metalinguística, centrada no código, objetivando usar a imagem (visual ou sonora) para facilitar a compreensão da mensagem; e, (vi) as propagandas veiculadas utilizam, de forma preponderante, a função conativa ou apelativa, centrada no receptor ou destinatário, objetivando agir sobre ele para suscitar ação ou reação.

Nesse ponto, vale fazer a consideração de que, a despeito dessas possíveis utilizações da linguagem audiovisual, temos que levar em conta que [26] a parte mais essencial da linguagem humana é a sua natureza inferencial (não demonstrativa, global, e possuidora de acesso livre às informações na memória) e, não, a sua estruturação em código, como estabelece o modelo de Jacobson [27].

A partir de nossa vivência em sala de aula e levando em conta os pressupostos estabelecidos na Introdução, bem como mais acima, entendemos que a utilização da linguagem audiovisual, i.e., do vídeo e da televisão, na educação deve apresentar os seguintes objetivos:

- Objetivo geral: formar telespectadores conscientes, ativos e críticos visando o domínio da 'imagem televisiva', evitando o domínio por 'ela', e contribuindo para a melhoria da qualidade do ensino;

- Objetivos específicos:

- Contribuir para integração entre as diferentes disciplinas;

- Contribuir para a formação de telespectadores capazes de dialogar com a imagem, tornando-se críticos e sensíveis às questões de seu espaço-tempo;

- Promover discussão, cooperação e trabalho, i.e., educação para a cidadania: aquela que mexe com a educação, exige posicionamento, e discussão; e,

- Desenvolver uma maior consciência de classe, um desejo de participação mais acentuado, com uma inserção mais eficaz nas diversas organizações sociais. 
A despeito dessas considerações, em geral, a sessão audiovisual é utilizada na escola, como nossa experiência revela, como um recreio, e às vezes como uma recompensa, concedida depois que um curso foi dado e, presumivelmente, aprendido.

Ao usar dessa forma a linguagem audiovisual, o professor priva-se de um grande auxílio no processo educacional. Se o filme ou a série de slides intervém depois da exposição da aula, seu papel limitar-se-á à repetição ou à ilustração, no sentido mais estrito deste termo. Como parece ser o único conhecido por muitos editores de manuais que não vêem na imagem mais do que uma distração destinada a tornar mais suportável a aprendizagem do conteúdo.

Ao contrário, imaginemos tudo o que se pode tirar do efeito de surpresa provocado pela projeção de um filme curto ou de uma série de imagens fixas no início da aula, limitando-se o comentário do professor a algumas informações sucintas, destinadas a situar a realidade que se projeta na tela. Ao clarear a sala, cem perguntas afloram aos lábios dos estudantes. Assim, elas poderão ser apreciadas, classificadas no quadro de giz, e a aula se organizará em torno das partes principais e das articulações destacadas, garantindo uma natural atenção por parte dos estudantes.

Então poderíamos afirmar:

Seguramente, não será necessário solicitar a atenção, manter artificialmente o interesse. Quem não ficaria atento para ouvir a resposta à sua própria pergunta?

Se for preciso, alguns slides, vídeos, etc, poderão voltar no decorrer da sessão, da aula. Descobrir-se-á neles o que passara despercebido. Encontrar-se-á a confirmação de uma primeira observação rápida demais apreendida de maneira ingênua.

É possível que no final do curso não se tenha esgotado o assunto e certos professores lamentem o tempo perdido. Na verdade, que importância tem isso, se os estudantes aprenderam a observar, a dispor e classificar os elementos desta observação. Em lugar de receberem a aula, eles a terão criado com seu professor.

Sem dúvida, tal método leva às vezes a fazer algumas alterações no programa, e até na lógica habitual da exposição, o que exige do professor sensibilidade e conhecimento do conteúdo.

Sendo o audiovisual um meio de comunicação [20] onde o emissor é o seu autor/produtor, o receptor é a assistência, a mensagem é o conteúdo transmitido, e o veículo de comunicação é o canal transmissor (vídeo, televisão, cinema, teatro, etc.) e considerando os pressupostos estabelecidos mais acima, podemos definir o audiovisual didáticopedagógico da seguinte forma:

Um veículo audiovisual didático-pedagógico é aquele que deve despertar a curiosidade e o interesse, que possibilite uma utilização informativa, formativa, recreativa, e educativa à assistência, possibilitando uma utilização crítica, estimulando o telespectador a dialogar com a imagem (áudio e visual) para refazer a mensagem a partir da sua leitura, e cujas linguagens escolhidas melhor se adequem ao êxito de seu objetivo, enfatizando a subjetividade, a característica informativa, subvertendo e transgredindo as normas conservadoras (no que couber), buscando o contato entre emissor e receptor, facilitando a compreensão da mensagem ao usar o próprio código, e suscitando a ação ou reação da assistência, observando, também, a natureza inferencial da linguagem humana; levando em conta os seguintes critérios:

- deve considerar os pré-requisitos;

- deve ser rigoroso e claro em relação aos conceitos utilizados;

- deve utilizar os elementos culturais da sociedade a que se destina.

\section{ESCOLA AUDIOVISUAL}

De todas as conquistas da tecnologia moderna, a televisão é, sem dúvida, a que alcança o maior número de pessoas e que exige o maior grau de preparo técnico e cultural para ser consumido. Suas técnicas de motivação garantem um contingente fiel e crescente de atentos consumidores. Não sem razão é usual a afirmação 
de que o aparecimento de inúmeras máquinas de comunicação (da fotografia às novas tecnologias) produziu novos fatos culturais e estabeleceu "um rearranjo na própria noção de cultura, na medida em que essas máquinas vão se constituindo códigos" [29].

A análise dessas técnicas é o primeiro ponto ao qual o educador deve estar atento, não no sentido de reproduzi-las no processo de educação formal, mas no sentido de positivar seus efeitos a partir da intervenção mediadora. A escola não tem por que assumir um sentimento de culpa diante da sua 'falta de brilho' (monotonia), em comparação com a mídia.

O estudante chega cansado à sala de aula, seus sentidos estão exacerbados pela estimulação artificial que recebem. Desse modo, as técnicas de motivação para a atividade organizada, disciplinada e silenciosa da aprendizagem racional, devem orientar-se para reconduzir o educando ao equilíbrio dos sentidos, sem o que será muito difícil captar-lhe a atenção e interesse.

A escola não deve competir com a mídia, mas travar com ela um jogo dialético.

Esta seria, então, um exemplo, ao nosso ver, de uma Escola Audiovisual voltada para a formação de cidadãos.

\section{ALGUMAS CONSIDERAÇÕES SOBRE O USO DA TELEVISÃO E DO VÍDEO NA SALA DE AULA A PARTIR DA PERSPECTIVA DE PROFESSORES DO ENSINO MÉDIO}

Sendo os programas de televisão e do vídeo produções do ser humano, eles são produtos não neutros estando sujeitos às limitações filosóficas, ideológicas e culturais de seus autores. Dessa forma, a sua escolha deve ser cuidadosa: é necessário por parte do educador, selecionar criteriosa e criticamente os programas a serem adotados, prevalecendo, na escolha, a qualidade e a utilidade, tendo como objetivo adequá-lo ao contexto sócio-econômico e cultural do educando, procurando obter um rendimento máximo possível do aprendizado.

Essa observação, resultado do nosso estudo das funções e linguagens do audiovisual e que culminou com a definição sugerida acima, e a nossa vivência no dia-a-dia da sala de aula, nos fez despertar o interesse pelo estudo da utilização a televisão e do vídeo na sala de aula.

Como é sabido, o trabalho com TV e vídeo em sala de aula faz parte da denominada $e d u$ cação para a cidadania [30].

A TV, como recurso audiovisual é um material rico, de múltiplas leituras. Além de ser um veículo de informação e de formação.

Ele apresenta múltiplas leituras, pois, como toda linguagem audiovisual,

$$
\begin{aligned}
& \text { solicita constantemente a } \\
& \text { imaginação e reinveste a afetivi- } \\
& \text { dade com um papel de mediação } \\
& \text { primordial no mundo, enquanto } \\
& \text { que a linguagem escrita desen- } \\
& \text { volve mais o rigor, a organizaçấ, } \\
& \text { a abstração e a análise lógica [24]. }
\end{aligned}
$$

Logo, a linguagem audiovisual desenvolve múltiplas atitudes perceptivas.

É um veículo de informação, pois, [16] informação, na sua concepção antropomórfica, está ligada com mensagem, dados, ou notícia. Portanto, sob essa concepção, informação é entendida "como mensagem linguística, significativa e inédita (para o receptor), transmitida entre seres humanos" [16], implicando três características principais:

a) sua existência e/ou transmissão dependeria do recurso à linguagem simbólica humana;

b) a uma dada informação estaria necessariamente associado um significado, ou seja, o emissor transmitiria uma informação com a intenção de que o receptor a interpretasse de uma maneira convencionada;

c) o caráter de novidade, ou ineditismo, da informação transmitida, relativamente ao conhecimento prévio do receptor [16].

Logo, o audiovisual é um veículo de informação por lidar com mensagens, dados ou notícias. 
Ademais é um veículo de formação, pois, como estabelecemos, educação é comunicação, porquanto "é diálogo, na medida em que não é a transferência de saber, mas um encontro de sujeitos interlocutores que buscam a significação dos significados" [2]. Reciprocamente, comunicação é educação, pois, como colocado por Beltrão e Quirino, entre as atividades da comunicação [31] (editoração, jornalismo, educação, relações públicas, propaganda, pesquisa em comunicação, e entretenimento), para a educação, em si, é estabelecido que:

[é um] processo de edição
e emissão de mensagens desti-
nadas ao ensino e aprendizagem
através de materiais e equipa-
mentos mecânicos, elétricos e/ou
eletrônicos de alcance universal
sobre temas científicos, artísticos e
técnicos-profissionais, utilizando-
se métodos didáticos, com vistas
à formação e/ou aperfeiçoamento
da bagagem intelectual e vivencial
da audiência [31];

sendo que, ainda existe o próprio conteúdo educativo contido nas outras seis atividades da comunicação especificadas no texto de Beltrão e Quirino [31]. Logo, o audiovisual é um veículo de formação por ser um meio de comunicação.

O uso da TV e do vídeo auxilia o educador a desenvolver um ensino que possibilite a aproximação do saber, além de alterar as relações ensino-aprendizagem na sala de aula. O saber até então do professor, do livro didático, das revistas, dos jornais, etc vai conviver com o saber do audiovisual.

A TV e o vídeo, em última instância, como qualquer outro meio de comunicação, facilitará aos estudantes o entendimento do mundo em que vive; ajudará a elaborar e resolver situações-problema, superando a mera verbalização de conteúdos; estimulará o trabalho em grupo, superando o individualismo; auxiliará os estudantes a encontrarem um método de estudo, um método de pesquisa, de aproximação do saber desejado, o que, consequentemente, justifica a existência da própria escola.
A televisão é um processo que consiste em reproduzir, transmitir e captar à distância, por meio de ondas eletromagnéticas, uma série de fotografias em rápida sequência, acompanhada de som. É o meio de comunicação de maior audiência do mundo, sendo o instrumento típico da denominada 'Cultura de Massa' [31].

Entre seus objetivos, podemos destacar os que seguem $[20,31]$ :

a) produzir diversão, idéias, educação e notícias;

b) exercer influência na formação da opinião pública, marcando profundamente o estilo de vida e o comportamento dos povos (frequentemente, inclusive, é usada como uma arma decisiva para os confrontos políticos [32]); e,

c) prestar [30], se colocada a serviço da difusão da cultura, imensa contribuição ao progresso da humanidade, em particular, no desenvolvimento dos países carentes em avanços científicos, tecnológicos, técnicos e educacionais compatíveis com as necessidades e aspirações dos respectivos povos.

A televisão tem a sua linguagem peculiar, bem como seus meios próprios de expressão artística, através da imagem e do som, i.e, da linguagem audiovisual, além do que "a televisão lida com vários saberes e vários campos sociais" [33].

Vídeo, de acordo com Moran, significa:

uma forma de contar multilinguística, de superposição de códigos e significações, predominantemente audiovisuais, mais próxima da sensibilidade e prática do homem urbano e ainda distante da linguagem educacional, mais apoiada no discurso verbal-escrito [24].

Entre seus objetivos, podemos destacar os seguintes: 
a) propiciar a análise da informação, possibilitando "professores e alunos a perceber melhor as possibilidades e limites da televisão e do jornal como meio informativo" [24];

b) produzir diversão, idéias, educação e notícias;

c) sensibilizar e conscientizar as pessoas; e,

d) resgatar, documentar, preservar e divulgar diferentes manifestações culturais.

Como a televisão, o vídeo tem a sua linguagem peculiar, bem como seus meios próprios de expressão artística, através da imagem e do som, ou seja, da linguagem audiovisual.

O conjunto dessas observações, resultado do nosso estudo das funções e linguagens do audiovisual, em particular, da televisão e do vídeo, e que culminou com a definição dada mais acima, juntamente com a nossa vivência no diaa-dia da sala de aula, nos possibilitou levantar as seguintes questões acerca da televisão e do vídeo:

- a formação dos professores versus o problema da utilização do audiovisual;

- a necessidade de uma definição do significado de audiovisual pelo professor, com o objetivo de entender a sua função;

- a transformação do professor em telespectador crítico do audiovisual;

- os critérios utilizados na adoção do audiovisual na sala de aula;

- a adoção do conteúdo veiculado no audiovisual como fonte única e verdadeira;

- a falta de roteiros para os audiovisuais dirigidos às áreas específicas do conhecimento;

- a não adoção do uso do audiovisual na sala de aula e as consequências para a formação do cidadão (ou de forma semelhante, a importância do audiovisual na formação de uma consciência crítica do cidadão - a questão de ser o dominado versus ser o dominador);

- a falta de uma produção regional satisfatória e a escassez de material nas locadoras e videotecas;

- a escola viabilizando uso do audiovisual ainda que não exista uma política nacional efetiva;

- o fracasso da escola e a sua relação com a leitura crítica das mensagens audiovisuais intimamente interligados.

Passemos, na sequência, a analisar cada uma dessas questões, com o objetivo de encontrar possíveis alternativas de solução, segundo as nossas perspectivas. Nesse estudo consideraremos, também, as discussões que ocorreram na palestra 'Um Estudo Crítico do Uso da Televisão e Vídeo na Sala de Aula' [3], onde foram constituídos, por professores, grupos de trabalho para avaliações dessa temática.

No que se refere à $1^{a}$ questão não é desconhecido que na sua formação acadêmica, os professores não tiveram acesso a esses meios de comunicação. Em particular, quando referidos à pergunta se tiveram algum contato com esse tema, professores que participaram das discussões ocorridas na palestra 'Um Estudo Crítico do Uso da Televisão e Vídeo na Sala de Aula' [3] responderam que:

[na] nossa formação profissional não contamos com esse recurso, daí a dificuldade que alguns profissionais encontram em utilizá-lo adequadamente. Entendemos que a utilização correta desse recurso irá ser de grande ajuda para o professor desenvolver o seu trabalho, mas, para isso, ele deverá ser preparado através de cursos, seminários, etc. para que, através de uma visão crítica, ele possa despertar o interesse dos estudantes diante do mundo onde eles vivem [3]. 
Assim, podemos afirmar que durante a formação acadêmica dos professores não é criado o hábito de utilização dos meios de comunicação, ficando a estrutura oferecida pela academia somente voltada para a limitação ao quadro e ao giz, em geral. O ideal seria a criação de uma matéria específica nas universidades, nos cursos de licenciatura, que trabalhasse a questão da utilização dos meios de comunicação em sala de aula.

Levando em conta a $2^{a}$ questão, a partir do estudo desenvolvido na segunda seção deste trabalho, acreditamos que, sendo o audiovisual didático-pedagógico um auxiliar do professor no processo ensino-aprendizagem, este deveria ter uma clara consciência do seu significado. Todo professor deveria, do ponto de vista pessoal/acadêmico, estabelecer uma definição do significado do audiovisual didático-pedagógico, com o objetivo de entender a sua função, para poder utilizá-lo como auxiliar em sua tarefa de educador. Obviamente, devido à dinâmica da procura do saber, essa definição seria somente um parâmetro inicial que o professor melhoraria durante a sua vida acadêmica buscando a plenitude dela.

Observamos, também, aqui que a boa formação do professor é condição sine qua non para que essa compreensão do conceito de audiovisual didático-pedagógico ocorra. Nesse sentido, os cursos de formação de professores devem criar condições em seus currículos que viabilizem não só a 'leitura' crítica de audiovisuais, mas também, as etapas de sua produção, além de uma compreensão do discurso e da linguagem a eles subjacentes.

Para abordarmos a $3^{a}$ questão, consideremos, inicialmente, um fato importante relacionado com a influência da televisão na vida das pessoas. Uma das questões relevantes suscitadas pela presença da televisão é a sua influência sobre as crianças e adolescentes. A TV entra na vida da criança quando esta ainda nada conhece do mundo, antecipando brutalmente uma série de experiências que de outro modo só viriam mais tarde; dá-lhe uma visão prematura de realidades chocantes, inclusive no que diz respeito ao sexo; bombardeia-a com slogans e jingles comerciais, com aven- turas de super-heróis que avassalam a imaginação; toma-lhes tempo de brinquedos, de estudos e de sono; ensina-lhe um vocabulário peculiar; é responsável, enfim, por uma série de influências negativas e traumas da mente infantil. Tais perturbações surgem porque as crianças são incapazes de distinguir entre o mundo imaginário, que lhes é mostrado, e o mundo real. Nesse sentido, um aspecto importante na formação dos professores, voltado para a sua postura crítica do audiovisual, é a compreensão dessa influência nas crianças para propiciar um uso adequado quando estiver formado.

Ainda nessa linha de análise e seguindo as considerações de Rubim no que tange à influência dos meios de comunicação na cultura das pessoas, temos que "os limites entre realidade e fiçã̃o tornam-se tênues. Imbricadas, parecem ser ambas puras criações da comunicação mediática" [33]. Assim, a formação audiovisual dos professores tornase um ponto importante para a compreensão desse aspecto, pois, em relação ao conteúdo audiovisual "muito mais do que transmitir informações, trata-se de criar determinados estados emocionais com os quais o telespectador pode se identificar. Perdendo-se os limites entre o discurso ficcional e o discurso que pretende reportar a realidade" [33].

Além desse aspecto importante para uma boa postura enquanto telespectador crítico, não podemos desconsiderar o fato de que, de acordo com as discussões ocorridas na palestra 'Um Estudo Crítico do Uso da Televisão e Vídeo na Sala de Aula' [3] "o professor tem resistência em utilizar recursos novos, [pois] tem medo do novo; [são] tradicionais" [3]. Novamente pontuamos a necessidade de melhor qualificação na formação docente na discussão do uso das tecnologias, sua importância e necessidade, como já visto anteriormente.

Como condição necessária para tornar-se um telespectador crítico, o professor também deve conhecer o conteúdo que estará sendo abordado no audiovisual, o que permitirá tratar do assunto e amadurecê-lo para expor à turma. Por mais que se façam críticas ao audiovisual, em particular aos programas televi- 
sivos, sempre existirão pontos na programação que vão ajudar na formação de consciências.

A análise da $4^{a}$ questão suscita questões como as que seguem: Como seriam utilizados a televisão e o vídeo no cotidiano da sala de aula? Com que objetivos?

Podemos responder essas questões dizendo que servem como motivação para o assunto da aula e como interligação entre a vivência do estudante e o assunto a ser estudado, tendo como objetivo a ampliação do conhecimento, além da promoção de um estudo crítico e reflexivo de sua realidade, permitindo-lhe um maior discernimento e participação na construção desse saber.

Nesse sentido, alguns critérios para a adoção do audiovisual devem ser seguidos:

- deve ser pensado inicialmente qual o papel que o vídeo e a televisão vão desempenhar,

- deve existir uma motivação inicial para que os estudantes se interessem e associem o que foi dado em sala de aula, sendo a motivação importante para criar um clima de interesse pelo conteúdo a ser trabalhado,

- os temas devem favorecer a participação dos estudantes.

- os temas devem ter uma imagem e linguagem clara e acessível, facilitando a compreensão do assunto em questão,

- devem ser utilizados como um recurso audiovisual, que objetive uma perfeita compreensão do assunto abordado,

- os temas devem despertar o interesse para um determinado assunto,

- devem ser escolhidos de acordo com o conteúdo que está sendo dado,

- devem ser escolhidos de acordo com o interesse dos estudantes,

- devem ser escolhidos de forma diversificada, devido ao aspecto da época, do recurso, etc., por exemplo, slides para o curso de geografia, jornais, vídeos,
- devem despertar no estudante o senso crítico, e estimular portanto a criticidade em sala de aula.

- as fitas de mídia devem ter duração que não 'cansem' os estudantes,

- devem possibilitar ao estudante a pesquisa, a formulação e a elaboração de um filme.

A $5^{a}$ questão, se ocorrer, revelará uma grande limitação dos professores no que se refere à sua formação específica e, também, à sua formação pedagógica. Em termos de sua formação específica, ficaria patente a sua dependência com o conteúdo veiculado, sem poder de análise e comparação com outros meios de comunicação e com seus próprios conhecimentos. No aspecto de sua formação pedagógica, ficariam limitados, tais professores, a um discurso peculiar, o discurso audiovisual, que como vimos é também merecedor de críticas, como estabelecido na análise da $3^{a}$ questão.

Agindo dessa forma, o audiovisual didáticopedagógico deixará de ser um veículo complementar que auxilia o processo de ensinoaprendizagem, passando a ser o veículo principal desse processo, o dono do discurso. Não podemos perder de vista que,

no Brasil, a comunicação se desenvolveu de forma antidemocrática. Não se trata somente do monopólio da Globo, mas de monopólios em geral que existem no campo da divulgação. O Grupo Abril, por exemplo, controla pelo menos metade das publicações de revistas no Brasil. Quatro cadeias controlam a televisão... Então, constitui-se uma comunicação monopolizada, o que significa um forte controle do acesso à dimensão pública por esses meios [33].

Podemos analisar a $6^{a}$ questão, pelo menos, sob dois ângulos. Como dito mais acima, na 
abordagem da $3^{a}$ questão, sempre existirão pontos na programação dos meios de comunicação que poderão ajudar na formação de consciências, ainda que carreguem um discurso específico. Assim, torna-se necessário que o professor tenha conhecimento da programação existente para que possa indicar aos educandos roteiros interessantes para ajudar nas discussões em sala de aula, bem como tenha conhecimento dos conteúdos específicos de sua área de atuação para que faça uma análise crítica, em relação aos conteúdos veiculados, dos temas indicados para os estudantes.

$\mathrm{O}$ outro ângulo de análise dessa questão repousa no fato de que existe uma pequena quantidade de programações interessantes. De acordo com os professores que participaram das discussões ocorridas na palestra 'Um Estudo Crítico do Uso da Televisão e Vídeo na Sala de Aula' [3], a programação audiovisual (particularmente a da televisão),

além de alienante em
princípio, é na essência res-
ponsável pela 'desgraça do povo
brasileiro'. Pouquíssimos são
os canais que trazem algo de
proveitoso para o estabelecimento
de nossa cultura brasileira. Es-
timulam determinados canais,
em sua programação, a prosti-
tuiçâa e a marginalidade, quer
seja através de novela, quer seja
através de filmes, estes que são os
verdadeiros 'enlatados' dirigidos
para aumentar a miséria de países
do 3o mundo, no caso, o Brasil
[3].

Seguindo ainda as considerações de tais professores,

os programas de TV que ainda instruem, até certo ponto, não têm exibição no horário nobre, pois nele é específico para a grande audiência com o intuito de proteger ao market dos grandes cartéis que manipulam a economia brasileira, decretando a miséria total dos nossos jovens e nossas crianças. A programação educativa está, de ordinário, em mãos de entidades que não proporcionam os meios de competir com os grandes grupos que têm o poder da comunicação no nosso país. [Em geral, a televisão] apresenta uma programação massificante, distrativa e sem maiores preocupações com a formação dos indivíduos. Apesar disso, existem programações específicas dentre os vários canais, a exemplo de telejornais, documentários, e programas de entrevistas, por terem um caráter informativo [3].

Observemos que tais considerações entram em consonância com a assertiva estabelecida por Carmen Lúcia José, que assevera que:

em todos os tempos, as
produções culturais estiveram sob
os olhos atentos dos organizadores
da ordem sócio-econômico-
política que nunca acreditaram-na
inocente e muito menos desin-
teressada. Se assim, melhor
então dotá-la de função contro-
ladora para que seus caracteres
- binárias, opositiva e de es-
pelhamento - pudessem estar
solidamente construídos quando
dos momentos de confronto com
os fatos não-culturais [29].

Vemos, portanto a necessidade de reafirmarmos o critério estabelecido na $4^{a}$ questão relativo à adoção do audiovisual que coloca também a possibilidade de pesquisa, formulação e elaboração de filmes, por parte dos próprios estudantes, o que possibilitaria a produção, ou participação nesta, em seus bairros, em suas comunidades. Como consequência, os cursos de formação de professores devem se ocupar também, com a própria produção do audiovisual.

No tocante à $7^{a}$ questão, que traz a possibilidade de não adoção do audiovisual em sala 
de aula, observamos uma atitude que vai de encontro à denominada "Era da Informação". Para Carmen Lúcia José,

$$
\text { (...) o } 3^{o} \text { milênio já está }
$$
sendo cognominado como a Era da informação, [e] parece necessário $e$ urgente retomar alguns pontos essenciais da cultura (seus universais, por exemplo) no sentido de, mais uma vez, readequar a noção aos novos tempos, verificar que tipo de parceiro ela atende $e$ é interferida e como será a convivência com a comunicação, com as artes e até mesmo com as novas tecnologias no sentido de manterse como um dos aspectos da inteligência, humana ou não [29].

Por outro lado, como atender ao preceito legal que assevera que a educação deve [34]:

(...) promover a divulgação
de conhecimentos culturais,
científicos e técnicos que con-
stituem patrimônio da hu-
manidade e comunicar o saber
através do ensino, de publicações
ou de outras formas de comu-
nicação;
(...) [destacar] a educação
tecnológica básica, a compreensão
do significado da ciência, das
letras e das artes; o processo
histórico de transformação da so-
ciedade e da cultura; a língua
portuguesa como instrumento de
comunicaçâa, acesso ao conheci-
mento e exercício da cidadania;
(...) [35].

Assim, adotando o audiovisual de forma crítica na sala de aula, estaremos propiciando ao estudante, em todos os níveis de ensino, uma formação de uma consciência crítica do cidadão, condição necessária para ser o autor de suas próprias decisões.

$\mathrm{Na}$ análise da $8^{a}$ questão, observamos que alguns pontos já foram tocados na questão anterior quando foi estabelecido que existem poucos programas educativos. Não é desconhecido que as televisões colocam tais programas em horários inadequados.

Além disso, a produção regional é insatisfatória, merecendo um olhar por parte do poder público para permitir um equilíbrio em termos da sociedade brasileira, respeitando as suas diferentes localidades, suas diferentes associações, suas diferentes culturas populares. Como estabelecido em [36]:

- Como ter garantido o direito de apresentar à população as produções independentes e as mensagens produzidas a partir dos interesses de grupos específicos da sociedade (sindicatos, organizações não-governamentais ou populares, comunidades)? (...).

- Como usar os meios de comunicação disponíveis para preservar a cultura nascida e desenvolvida nas regiões periféricas do país? (...) [36].

O enfrentamento dessas questões só pode se dar através de movimentos coletivos, daí a necessidade de uma formação crítica dos estudantes, o que implica em uma formação crítica dos professores no aspecto do uso do audiovisual em sala de aula, ajudando a formar cidadãos.

Ainda que seja um processo difícil sem um apoio institucional, a produção de material audiovisual pode ser estimulada, como já aludimos mais acima, possibilitando a criação de alternativas independentes.

Ainda que sejam escassas as ações governamentais, citaremos uma na produção de material audiovisual, o Projeto Vídeo-Escola [37].

A $9^{a}$ questão remete a um papel que a escola poderia ter, em consonância com os professores, na difusão do uso do audiovisual propiciando uma formação cidadã crítica. A inexistência de uma política nacional de comunicação é um fato [36], no entanto, os professores ao utilizarem em sala de aula o audiovisual, seguindo os critérios estabelecidos na $4^{a}$ questão poderiam estar ajudando na criação de alternativas 
que a médio e longo prazo se tornariam efetivas. Essa atitude, no entanto esbarra também na formação dos professores no que tange à comunicação, pois não é comum a existência de matérias que versem sobre tal tema.

Dessa forma, torna-se importante que sejam criados nos cursos de licenciatura disciplinas que se ocupem com a utilização dos meios de comunicação na sala de aula, voltados também para a produção. Essa ação universitária teria como princípio a prática das atividades de ensino, pesquisa e extensão, na medida em que: (i) seria ensinado o ato do uso dos meios de comunicação, (ii) possibilitando a compreensão de sua produção - pesquisa -, (iii) pensando na extensão de suas mensagens quando os objetos de comunicação fossem veiculados nas comunidades e grupos específicos da sociedade pelos estudantes-cidadãos críticos. Com isso a própria escola assumiria as atividades de pesquisa e extensão.

No que se refere finalmente à $10^{a}$ questão, podemos concluir, a partir de nossa experiência na sala de aula, que o fracasso da escola [38] está ligado, em linhas gerais, ao fato das escolas não assumirem as atividades de pesquisa e extensão, como foi frisado em Miltão et elli [4],

o que leva os professores, mal formados, a restringirem-se na transmissão de um saber já estabelecido, não abrindo perspectiva para a produção de novos conhecimentos; e os alunos, filhos de uma sociedade avessa à leitura, a aceitarem esse saber estabelecido sem resolverem os seus verdadeiros problemas sociais e culturais [4].

Não é desconhecido que esses fatos são consequências da escassez de uma política democrática efetiva de ensino e de comunicação [36, 39-43], o que não deve impedir tentativas particulares, em seus pequenos universos, de resolução de problemas que estiverem ao seu alcance; estratégia já aludida em [4].

Quando colocamos a necessidade de que as atividades de ensino, pesquisa e extensão sejam cultivadas de forma indissociáveis nas es- colas, como uma forma de enfrentar o problema aludido da relação entre o fracasso da escola e a crise da leitura, em particular da leitura crítica das mensagens audiovisuais, está em nossa mente o significado da natureza de uma instituição educacional que lida com o conhecimento humano, e a concepção de educação e ensino-aprendizagem que assumimos.

Defendemos a tese de que uma Instituição Educacional, de qualquer nivel, é aquela cujos pilares são as atividades de ensino, pesquisa e extensão, e que estas obedecem ao princípio da indissociabilidade, sendo que as suas estruturas acadêmica e administrativa devem estar relacionadas com o cultivo de tais atividades acadêmicas.

Acreditamos que a atividade de ensino em uma escola deve ser entendida como um processo relacional e de ação cultural, assentado no pressuposto epistemológico construtivista e dialógico [6, 9], na direção da formação ou modificação da conduta humana, configurando-se, assim, como um processo de duas vias: o processo de ensino-aprendizagem, onde os dois atores, o professor e o estudante, interagem na busca de seus objetivos [4].

Do ponto de vista do professor, a prática dessa atividade deve significar a convivência com o outro (o estudante), para tentar entendêlo psicológica e socialmente, respeitando as suas virtudes e ajudando a superar as suas lacunas, aqui entendidas, na visão de Paulo Freire, como a "compreensão mágica ou ingênua da realidade" [7], para com isso propiciar "condições onde possam se estabelecer reciprocidade intelectual e cooperação ao mesmo tempo moral e racional" [9].

Como a nossa própria experiência nos tem mostrado e sistematizando as considerações de Berchem [11] e Demo [12] sobre a ação do professor, 
para implementar a sua ação pedagógica ele pensa, imagina, descobre, cria situações, atinentes ao seu Campo do Saber, que propiciarão não só o seu planejamento, preparação de aulas, correção de trabalhos e provas, mas, principalmente, propiciarão o bom entendimento das explicações que serão argumentadas em classe ou no atendimento e orientação extra classe, no sentido de fazer com que o estudante trabalhe com mão própria, elabore as suas próprias questões, dedique-se ao seu objeto de estudo, tenha objetividade, examine de forma crítica/refletida as situações que se apresentam, busque sempre possibilidades contrárias, seja autocrítico, tenha prudência na afirmação definitiva, verifique sempre os limites e a validade das afirmações, escute as causas, tenha autonomia intelectual, e tenha compreensão e colaboração mental para compreender o ponto de vista do outro [4].

Assim, articulam-se a pesquisa, o ensino e a extensão no próprio processo formativo do estudante, "pois, neste processo estão inerentes o processo de produção do conhecimento (pesquisa) e a relação com a própria sociedade (extensão)" [4].

Também, ainda em termos da atividade de ensino, considerando a natureza do conceito de professor e sua relação com a atividade de pesquisa, estabelece Demo que:

em termos de modernidade tecnológica e educativa - e no fundo, na mais bela tradição educativa - professor define-se em primeiríssimo lugar pela capacidade de produção própria de conhecimento. Como decorrência necessária, deve ensinar. (...). Não deve haver dicotomia entre pesquisar e ensinar (...): quem pesquisa, deve ensinar, quem ensina, só o pode fazer, porque pesquisa. (...). O mero ensino não combina com o desafio tecnológico, como, no fundo, nunca combinou com educação emancipatória [12].

No aspecto da natureza do conceito de professor e a sua relação com a atividade de extensão, reafirmamos as considerações já feitas na análise da nona questão em Miltão et alli [4] que estabelece que

a leitura [das mensagens audiovisuais] tem que ser um ato cultural, ou seja, [tal] leitura tem que inquietar o [leitor-espectador], fazê-lo pensar, sentir e reelaborar; enfim, a leitura, enquanto um ato cultural, está intimamente ligada ao modo de produção do conhecimento humano, o qual se caracteriza por uma permanente interação entre pensar, sentir $e$ fazer: quando [lemos-assistimos] devemos pensar nas informações extraídas dos [textos-imagens], compará-las com o nosso universo cultural, sentindo essa confrontação, e então reelaborar o nosso pensamento (fazer) [4].

Nesse sentido, não deve haver dissonância entre a extensão e o ensino. Ademais, em termos da formação política dos estudantes, esta

pode ser motivada também
por estratégias extrínsecas ao
currículo, como atividades cultu-
rais, iniciativas sociais (prestação
de serviços à comunidade),
eventos comunitários, etc. [12],

que devem ser utilizadas pelo professor no processo de ensino-aprendizagem do estudante como atividades complementares, porém formativas.

No que tange à atividade de pesquisa acreditamos, por um lado, de acordo com Demo, que esta: 
representa a estratégia própria de produção científica, seja na descoberta de relaçôes reais objetivas (são encontradas, não criadas), seja na construção de posturas dialéticas que valorizam a história (...), (e por outro, que ela é um] princípio educativo, a partir da questão emancipatória [12];

sendo compreendida, como uma "atitude de vida, ou seja, estratégia básica de autoconstrução" [12].

Em termos da importância da pesquisa para a atividade de ensino, nos diz Demo que:

o professor-pesquisador, [ao ser] definido como alguém que [sabe] produzir conhecimento próprio, leva o aluno a fazer o mesmo, mutatis mutandis. [Portanto, a] função do professor não é 'dar aulas', mas fazer o aluno trabalhar com mão própria, sob orientação [12].

Em termos da extensão, defendemos que:

deve ser compreendida como
o conjunto de atos pratica-
dos pela escola no sentido de
integrar-se à sociedade, aten-
dendo as finalidades básicas do
compromisso político-social e da
prática acadêmica [4].

Em outras palavras, a extensão deve ser compreendida como [44]:

uma via de mão dupla, com trânsito assegurado à comunidade acadêmica que encontrará, na sociedade, a oportunidade da elaboração da práxis de um conhecimento acadêmico; no retorno à [escola], docentes e discentes trarão um aprendizado que, submetido à reflexão teórica, será acrescido àquele conhecimento [14].
A extensão, dessa forma, constitui-se no elemento articulador do ensino e da pesquisa (desenvolvidos a partir da escola) com a sociedade.

Vemos, então, seguindo Miltão et alli

que o fracasso da escola, a despeito de sua causa estar vinculada macroscopicamente com políticas públicas, pode ser enfrentado, no mundo microscópico das escolas, com atitudes propositivas de seus docentes, por exemplo, no âmbito da tentativa da prática das atividades docentes de ensino, pesquisa e extensão de maneira indissociável. Pelo que expusemos na análise dessa questão [a $10^{\circ}$ ], essa prática pode possibilitar a emancipação, no sentido da conscientização, dos agentes do processo educativo, os educadores e os educandos, fator importante na superação do fracasso escolar. Uma conscientização que poderá ter como consequência, por parte desses agentes, o interesse pela busca do próprio conhecimento acumulado pela humanidade, condição básica para despertar a simpatia, o interesse, pela leitura [crítica das mensagens audiovisuais] [4].

Considerando a necessidade da leitura tornar-se um ato cultural, vemos como a atividade de extensão pode contribuir na solução desse problema a partir da conscientização dos indivíduos de sua capacidade de produção do conhecimento, no caso específico, a produção de audiovisuais.

Assim, da tentativa de superação do fracasso escolar, somos levados à possibilidade de superação da crise da leitura, em particular da crise da leitura crítica das mensagens audiovisuais.

Reciprocamente, podemos dizer que a leitura crítica das mensagens audiovisuais poderá ser um fator importante no enfrentamento do próprio fracasso da escola a médio ou longo prazos, pois teremos cidadãos conscientes 
de suas ações quando formados. Assim, a atitude plena das atividades de ensino, pesquisa e extensão, pelo que expusemos na análise dessa questão, poderá contribuir na transformação dos agentes do processo educativo em leitorestelespectadores quando considerarmos a concepção da atividade de ensino por nós defendida, contribuindo na minimização do fracasso escolar.

Assim, da tentativa de superação da crise de leitura crítica das mensagens audiovisuais, somos levados à possibilidade de superação do fracasso da escola.

A partir da análise dessas dez questões por nós levantadas, a respeito do uso do audiovisual, sistematizaremos as possíveis alternativas de solução propostas, segundo as nossas perspectivas.

No aspecto da formação dos professores, como vimos, deveria existir um tratamento mais orgânico da questão dos conteúdos que trabalhasse a sua seleção, estruturação e planejamento crítico. Nas discussões desses pontos, seriam tratadas também as questões relativas à leitura e escrita, enquanto produção do conhecimento, visando estimular, não só os professores em formação, mas os seus futuros estudantes para o ato da leitura crítica dos audiovisuais.

Em termos dos currículos universitários, isso poderia ser feito nas disciplinas de "Novas Tecnologias e Educação", "Didática", "Variáveis Educacionais e Pedagógicas do Ensino" e de "Comunicação" (do ponto de vista da discussão teórica desses temas), e nas disciplinas "Instrumentação para o Ensino", "Comunicação para o Ensino", "Metodologia para o Ensino" e "Estágio Supervisionado" (do ponto de vista da aplicação prática). Certamente, o estabelecimento por parte dos professores, de uma definição do veículo audiovisual didático-pedagógico seria possibilitado.

Também, no aspecto da formação geral dos professores,

a questão da natureza da atividade docente (nomeadamente, o desenvolvimento indissociável das atividades de ensino, pesquisa e extensão), deveria ser trabalhada nas disciplinas universitárias para que, quando formados, os professores agissem naturalmente como produtores de conhecimento como, de fato, são [4].

No aspecto da formação de conteúdos específicos de sua área de atuação, os currículos da licenciatura deveriam tratar em um grau mais aprofundado esses assuntos específicos. Em outras palavras, no currículo, além das disciplinas do ciclo básico, referentes aos conteúdos específicos, deveriam existir disciplinas que aprofundassem tais conteúdos específicos em um nível avançado, profissionalizante para permitir análises adequadas das mensagens audiovisuais, bem como, em termos de produção, possibilitar a elaboração de roteiros e filmes com transposições didáticas apropriadas de tais conteúdos específicos.

Em termos dos critérios para a escolha do audiovisual, a ser adotado em sala de aula, os professores deveriam considerar os seguintes aspectos: seleção criteriosa, com posição crítica (em relação ao conhecimento específico e à carga ideológica subjacente); levar em conta a realidade social, política e econômica dos estudantes; considerar a facilitação do processo de ensino aprendizagem (clareza, rigor das definições e conceitos, estruturação, apresentação e linguagem do conteúdo); e devem possibilitar ao estudante a pesquisa, a formulação e a elaboração de um filme.

\section{CONCLUSÕES}

No presente trabalho analisamos um importante aspecto sobre o audiovisual através de dez questões (formuladas a partir de nossa experiência em sala de aula): a sua utilização em sala de aula.

Estabelecemos alguns pressupostos em relação à concepção de educação, em relação ao processo de ensino-aprendizagem, em relação à atividade docente, e em relação ao audiovisual.

A partir daí, com o objetivo de propor uma definição do audiovisual, colocamos mais dois 
pressupostos: um relativo às suas funções e outro relativo às suas linguagens.

Então, levando em consideração a nossa vivência no dia-a-dia da sala de aula, levantamos as dez questões acerca do vídeo e da televisão, especificamente em relação ao seu uso.

Da análise dessas questões acerca do audiovisual, para os profissionais em atividade, do ponto vista estrutural, é necessário o corpo docente das escolas assumir as atividades de pesquisa e extensão [45] e, para tal, é importante a realização de seminários, com temas específicos sobre esse assunto, que deverão ser ministrados aos professores com o objetivo de aperfeiçoamento, em busca da compreensão da natureza das atividades de ensino, pesquisa e extensão e da importância delas como pilares de qualquer instituição educacional.

No que tange ao aspecto da formação dos professores nos cursos de licenciatura, as universidades devem adequar os seus currículos, principalmente, no tocante à visão de que as atividades de ensino, pesquisa e extensão são indissociáveis e formam os pilares das instituições educacionais, sejam elas creche, escola do ensino fundamental e médio ou universidade. Além disso, no aspecto dos conteúdos gerias, as disciplinas deveriam, também, tratar de questões relativas à leitura e escrita, enquanto produção do conhecimento, e no aspecto dos conteúdos específicos, deveriam existir disciplinas que aprofundassem tais conteúdos em um nível mais avançado.

Com esse estudo, a nossa expectativa é contribuir, ainda que ingenuamente, para a discussão sobre o audiovisual, visando dar a nossa parcela de ajuda nesse importante tema do conhecimento humano, na busca de novos rumos para a educação.

\section{AGRADECIMENTOS}

Gostaríamos de agradecer à Professora Raidalva, Vice-Diretora do turno da tarde do Colégio Estadual Mário Augusto Teixeira de Freitas, por sua visão ampla da concepção de atividade administrativa, o que possibilitou o desenvolvimento do nosso trabalho de pesquisa. Também, gostaríamos de agradecer aos colegas do Colégio que, direta ou indiretamente, participaram das discussões relativas à nossa pesquisa. Principalmente, gostaríamos de agradecer aos estudantes que se incorporaram entusiasticamente no projeto trazendo os seus sonhos e desejos na busca de uma educação mais ampla.
[1] Esse trabalho é resultado de pesquisas desenvolvidas entre os anos de 1993 e 1996, pelos então, professores do Ensino Médio na rede estadual, das disciplinas de (Física, História, Geografia e Português) no Colégio Mário Augusto Teixeira de Freitas da cidade de Salvador - BA.

[2] P. Freire, Extensão ou Comunicação? Rio de Janeiro: Paz e Terra (1983).

[3] M.S.R. Miltão, Um Estudo Crítico do Uso da Televisão e Vídeo na Sala de Aula. In: Semana Pedagógica do Colégio Estadual M. A. Teixeira de Freitas, Palestra, 1995. Salvador: Secretaria de Educação e Cultura do Estado da Bahia (1995).

[4] M.S.R. Miltão, M.T.M. Simões, D. Serra, C. Abreu, Considerações Gerais sobre o Uso dos Livros Didáticos a partir da Experiência de
Professores em Sala de Aula no Nível Médio. Caderno de Física 04, (1 e 2) 51 (2006).

[5] L. Pereira, M.M. Foracchi, (Orgs.), Educação e Sociedade. São Paulo: Companhia Editora Nacional (1987).

[6] W. de Faria, Teorias de Ensino e Planejamento Pedagógico. São Paulo: EPU (1987).

[7] P. Freire, Educação como Prática de Liberdade. São Paulo: Paz e Terra (1996).

[8] V.A. de Lima,Comunicação e Cultura: as Idéias de Paulo Freire. Rio de Janeiro: Paz e Terra (1981).

[9] M. da G. N. MIizukami, Ensino: as Abordagens do Processo. São Paulo: EPU (1986).

[10] J. Piaget, A Epistemologia Genética. São Paulo: Abril (1978).

[11] T. Berchem, A missão da Universidade na formação e no desenvolvimento culturais: a 
diversidade no seio da Universidade. Educação Brasileira 13, (27) 81 (1991).

[12] P. Demo, Qualidade e Modernidade da Educação Superior: discutindo questões de qualidade, eficiência e pertinência. Educação Brasileira 13, (27) 35 (1991).

[13] I.M. Sant'Anna, M. Menegolla, Didática: Aprender a Ensinar. São Paulo: Edições Loyola (1991).

[14] UNB. Extensão - A universidade construindo saber e cidadania. In: Encontro de Pró-Reitores de Extensão das Universidades Brasileiras, 1º Documento Final, 1987. Brasília: UnB (1989).

[15] A.B. de H. Ferreira, Novo Dicionário da Lingua Portuguesa. Rio de Janeiro: Nova Fronteira (1986).

[16] A. Pereira Jr., M.A. Gonzales, Informação, Organização e Linguagem. In: F.R.R. Évora, Espaço e Tempo, 1995. Campinas: Centro de Lógica, Epistemologia e História da Ciência UNICAMP (1995).

[17] H.H.N. Brandão, Introdução à Análise do Discurso. Campinas: Editora da Unicamp (1996).

[18] F. de Saussure, Curso de Linguística Geral. São Paulo: Cultrix (1969).

[19] M. Bakhtin, Marxismo e Filosofia da Linguagem: Problemas Fundamentais do Método Sociológico na Ciência da Linguagem. São Paulo: Hucitec (1986).

[20] C.A. Rabaça, G. Barbosa, Dicionário da Comunicação. São Paulo: Ática (1987).

[21] R. May, A Aventura do Cinema. Rio de Janeiro: Civilização Brasileira (1967).

[22] J. Ferrés, Vídeo e Educação. Porto Alegre: Artes Médicas (1996).

[23] J.M. Moran, Como ver Televisão. São Paulo: Paulinas (1991).

[24] J.M. Moran, Usos do Vídeo na Sala de Aula. In: Educação - Caminho para a Construção da Cidadania, Palestra, 1993. Salvador: IAT (1993)

[25] De acordo com Jakobson, para se ter uma idéia geral dessas funções, é mister uma perspectiva sumária dos fatores constitutivos de todo processo linguístico, de todo ato de comunicação verbal. O REMETENTE envia uma MENSAGEM ao DESTINATÁRIO. Para ser eficaz, a mensagem requer um CONTEXTO a que se refere (ou "referente", em outra nomenclatura algo ambígua), apreensivel pelo destinatário, e que seja verbal ou suscetivel de verbalização; um CÓDIGO total ou parcialmente comum ao remetente e ao destinatário (ou, em outras palavras, ao codificador e ao decodifi- cador da mensagem); e, finalmente, um CONTACTO, um canal físico e uma conexão psicológica entre o remetente e o destinatário, que os capacite a ambos a entrarem e permanecerem em comunicação [27].

[26] S. Auroux, J. Deschamps, D. Kouloughli, La Philosophie du Langage. Paris: PUF (1996).

[27] R. Jakobson, Linguística e Comunicação. São Paulo: Cultrix (1977).

[28] E.S.A. Sapir, A Linguagem. São Paulo: Perspectiva (1980).

[29] C.L. José, Revisão Contemporânea de Cultura. Jornal A Tarde, Salvador 11 jan. (1995).

[30] I. de O. Soares, Comunicação e Criatividade na Escola: Análise Crítica da Comunicação Mediante a Produção. São Paulo: Paulinas (1990).

[31] L. Beltrão, N. de O. Quirino, Subsídios para uma Teoria da Comunicação de Massa. São Paulo: Summus (1986).

[32] Contraponto, A Verdade Vale Mais do que a Versão. Boletim Conjunto Sindipetro/Stiep, Salvador, 02 dez. (1994).

[33] A.A.C. Rubim, Comunicação e Política. (Entrevista). Cadernos do CEAS 1, (135) 6 (1991).

[34] Observe que o Projeto de Lei de Diretrizes e Bases da Educação Nacional, subscrito pelo Deputado Florestan Fernandes, fruto das discussões com os movimentos populares e sociais, apresentava avanços muito mais significativos no aspecto da comunicação e a sua relação com a educação do que a Lei aprovada e que foi proposta e subscrita pelo Senador Darcy Ribeiro [43].

[35] Brasil. Lei $N^{o} 9.394$ de 20 de dezembro de 1996. Lei de Diretrizes e Bases da Educação Nacional. Brasília - DF. Legislação Federal.

[36] VV. AA., Por uma Política Democrática da Comunicação. São Paulo: Paulinas (1993).

[37] Como um exemplo de ações referentes à utilização do vídeo na sala, nós podemos citar o Projeto Vídeo-Escola. Ele foi criado em 1989, através do convênio da Fundação Banco do Brasil, Fundação Roberto Marinho e Secretarias de Educação Estaduais. Na Bahia, tal projeto foi estabelecido pelo Instituto Anísio Teixeira, IAT. O objetivo maior é buscar a melhoria da qualidade do ensino público brasileiro ao implantar nas escolas um dos recursos de telecomunicação mais eficiente, o vídeo. Em Salvador existem dois núcleos espécie de locadora - o IAT e o IRDEB (Instituto de Radiodifusão Educativa da Bahia), o qual atende o vídeo posto $[46,47]$. Além disso, 
podem ser citados filmes que existem no Instituto de Física da UFBA e que podem ser utilizados em sala de aula através de projetores adequados.

[38] Por Fracasso Escolar queremos dizer, dentre outras coisas, o não cumprimento do papel social da escola, a grande evasão dos estudantes, os altos índices de reprovação, o fracasso no domínio da leitura e escrita, a falta de capacidade da escola em lidar com a diversidade cultual dos estudantes, a má formação dos professores, a falta de reconhecimento profissional dos professores por parte das autoridades competentes, o descaso com a escola de modo geral.

[39] L.A. Cunha, M. de Góes, O Golpe na Educação. Rio de Janeiro: Zahar (1989).

[40] M.L.S. Ribeiro, História da Educação Brasileira. São Paulo: Cortez (1990).

[41] O. de O. Romanelli, História da Educação no Brasil. Petrópolis: Vozes (1988).

[42] E. Yunes, Por uma Política de Leitura. Nova Escola Ano V, (45) (1990).

[43] I. de O. Soares, A Nova LDB e a Comunicação: perspectivas profissionais para o terceiro milênio. Universidade 1, (1) 46 (1994).

[44] Adaptação do conceito de extensão estabelecido no texto da UNB [14].

[45] Como um exemplo de atividades de pesquisa e extensão desenvolvidas por docentes de uma instituição do segundo grau, podemos citar o trabalho intitulado "Estudo do Uso do Livro Didático, Televisão, Vídeo, Cinema e Teatro na Sala de Aula", por nós desenvolvido no Colégio M. A. Teixeira de Freitas, em Salvador, durante os anos de 1993 a 1996. O objetivo do trabalho foi analisar determinados conteúdos veiculados no livro didático, na televisão, em vídeo, no cinema ou no teatro, com o fito de utilizá-los na sala de aula. Resultados parciais foram apresentados na Semana Pedagógica do Colégio M. A. Teixeira de Freitas [3, 48] e foram aceitos para apresentação na $46^{a}$ Reunião Anual da SBPC em
1994. No entanto, por falta de um apoio efetivo do Colégio, não foi possível o deslocamento para a apresentação do trabalho no evento promovido pela SBPC. Um ponto importante a ser ressaltado foi o pioneirismo do desenvolvimento do projeto, no Colégio em questão, no aspecto de ser uma atividade de pesquisa desenvolvida por professores de uma instituição educacional do segundo grau. Após um árduo trabalho, em 1996 a direção do Colégio reconheceu a importância da atividade aprovando-a e divulgando-a pela Portaria 03/96 de março de 1996. No aspecto da orientação a estudantes, faziam parte desse projeto estudantes cuja participação, em linhas gerais, se dava a partir de discussões relacionadas aos conteúdos, por eles apreendidos em decorrência da leitura de algum livro didático, de algum programa veiculado na televisão, em vídeo, no cinema ou no teatro e seus possíveis aproveitamentos como conteúdos na sala de aula. Além disso, os estudantes produziam um jornal, por nós assessorado, de pequena circulação interna ao Colégio, onde as matérias, desenhos e cartoons relacionavam-se com os temas discutidos sobre os conteúdos por eles apreendidos. As discussões relativas ao trabalho ocorriam em reuniões, no próprio Colégio, com os docentes e no Passeio Público e na Biblioteca dos Barris, com os estudantes, sempre fora do horário das aulas.

[46] Instituto Anísio Teixeira. Projeto Vídeo Escola, Roteiros e Sugestões de Atividades para Uso do Vídeo em Sala de Aula. Salvador: IAT (1995).

[47] Iinstituto Anísio Teixeira. Uso do Vídeo na Escola. Educação - Caminho para a Construção da Cidadania. Salvador: IAT (1993).

[48] M.S.R. Miltão, Abordagem Crítica sobre o Livro Didático. In: Semana Pedagógica do Colégio Estadual M. A. Teixeira de Freitas, Palestra, 1994. Salvador: Secretaria de Educação e Cultura do Estado da Bahia (1994). 